Teologia Praktyczna 20(2019)

doi: $10.14746 /$ tp.2019.20.06

ORCID: 0000-0002-2684-862X

JOLANTA KOSTECKA

\title{
Spiralna koncepcja czasu w prawie kanonicznym - inspiracje pastoralne
}

Przedmiotem analizy w niniejszym artykule jest zagadnienie spiralnej koncepcji czasu w prawie kanonicznym, stanowiącej syntezę perspektywy kolistej (powtarzalność i ruch po okręgu) i liniowej (historycznej, chronologicznej) - jako źródła pastoralnych inspiracji. Pierwsza część opracowania nawiązuje do rozróżnienia pojęć „,czas” i ,wieczność”, następna wyjaśnia istotę spiralnej teorii czasu, a w dalszym toku wywodu zostały przedstawione konkretne przykłady zastosowania omawianej koncepcji w przepisach prawa kanonicznego, powszechnego i partykularnego, a także ich celowość w odniesieniu do szeroko pojętej posługi duszpasterskiej.

Rozważania na temat czasu i wieczności zajmowały umysły wielu pokoleń wybitnych filozofów i teologów. Liczne problemy współczesnego człowieka, takie jak poczucie braku czasu, nieustanny pośpiech i doświadczenia lęku przed śmiercią, łączą się z utratą zakorzenienia w wieczności, odejściem od tej perspektywy, którą mieli nasi przodkowie. Ich życie i sposób przeżywania czasu były spokojniejsze i bardziej intensywne, mimo że statystycznie umierali znacznie wcześniej. Patrzyli w przyszłość, oczekując wieczności, a ich rytm życia wpisywał się w cykl natury i roku liturgicznego. Dlatego też nie potrzebowali uczyć się jakże popularnego dziś „zarządzania sobą w czasie” (czas jest krótki, nie można go zmarnować, trzeba go dobrze zaplanować i wykorzystać); niejako intuicyjnie funkcjonowali zgodnie z zasadą św. Ignacego z Loyoli - „tu i teraz”, traktując życie w czasie (życie ziemskie) jako pielgrzymkę do wieczności, a bolesny moment śmierci - jako przejście do „,czasu, który się nie kończy".

W tym kontekście warto nadmienić, że troska o jakość przeżywanego czasu nie wynika tylko z ograniczoności naszego życia na ziemi, lecz w chrześci- 
jaństwie jest związana z kategorią zbawienia bądź zasługiwania na przejście do wieczności (czas jest człowiekowi dany i jednocześnie zadany). Należy więc na wstępie zwrócić uwagę na istotne rozróżnienie pojawiające się na kartach Pisma Świętego - pojęcia chronos i kairos. Chronos to czas ilościowy, niezależny, a w języku biblijnym również termin o zabarwieniu negatywnym - czas pusty, pogański, bezowocny. Kairos odnosi się natomiast do czasu przeżywanego świadomie, z wysiłkiem i zaangażowaniem, do podejmowanych wyborów i odpowiedzi na powołanie, czuwania i gotowości na nadejście czasów mesjańskich (Bielecki 1999, s. 41-59). Normy prawa kanonicznego, nawiązujące do konstrukcji czasu spiralnego i nadające kierunek działaniom duszpasterskim, uwypuklają znaczenie kairos - jako czasu niosącego nadzieję na wieczność, dającego szansę na zmianę i rozpoczynanie od nowa. Istotne jest, aby korzystając $z$ dotychczasowych doświadczeń i powracając do pewnych zdarzeń, przeżywać je w ruchu spiralnym - wchodząc wciąż na nowe, wyższe etapy rozwoju.

\section{Czas i wieczność}

Rozważania na temat pojęć pierwotnych, niedefiniowalnych - takich jak czas i wieczność - stanowią odwieczny problem filozoficzny i teologiczny. Znamienne są słowa św. Augustyna z Hippony zawarte w Wyznaniach (XI, 13-14):

Wszelki czas Ty uczyniłeś i jesteś przed wszelkim czasem, a czasu przed czasem - nie było [...]. Czymże więc jest czas? Jeśli nikt mnie o to nie pyta, wiem. Jeśli pytającemu usiłuję wytłumaczyć, nie wiem. Z przekonaniem jednak mówię, że wiem, iż gdyby nic nie przemijało, nie byłoby czasu przeszłego. Gdyby nic nie przychodziło nowego, nie byłoby czasu przyszłego. Gdyby niczego nie było, nie byłoby teraźniejszości [...]. Nie możemy więc właściwie mówić, że czas jest, jeśli nie dodajemy, iż zmierza on do tego, że go nie będzie (Augustyn, wyd. 2013, s. 349-350).

Definicje słownikowe i encyklopedyczne wskazują m.in., że czasem jest nieustanne trwanie, ciąg następujących po sobie chwil, okres, pora jakiejś czynności czy zdarzenia. Z czasem związane są terminy i wiek jako miara trwania życia. Człowiek liczy i odmierza czas i dzięki temu może określać chronologię wydarzeń. Czasu używa się do wskazywania kolejności zdarzeń; jest punktem odniesienia dla postrzegania wydarzeń, a w sensie językowym - rozróżnia się formę gramatyczną czasownika, pozwalającą ustalić relację czynności czy stanu do chwili wypowiedzi o nim - czas teraźniejszy, przeszły, przyszły (Gadacz 2002, s. 321; Dubisz 2006, s. 508-509). Wieczność, przed- 
stawiana w opozycji do czasu, w perspektywie chrześcijańskiej jest związana ze zmartwychwstaniem i końcem doczesnego świata. Zgodnie z objawieniem, po śmierci stanowiącej zakończenie ziemskiego życia, gdy nadejdą czasy ostateczne, nastąpi przejście do wiecznego życia albo wiecznej śmierci. Wieczność jako „czas, który się nie kończy”, była postrzegana jako wyzwolenie od kruchości i ulotności życia. Wraz z utratą wiary w życie po śmierci zmieniało się jednak spojrzenie na czas ziemski, wzmacniając poczucie szybkiego i nieuchronnego upływu czasu i zwiększając pragnienie jego maksymalnego wykorzystania.

W tym kontekście wyzwaniem dla nurtu nowej ewangelizacji jest doprowadzenie współczesnego człowieka do wiary i przywrócenie mu w ten sposób perspektywy wieczności i nadziei zmartwychwstania, pomoc w dostrzeżeniu sensu codziennego życia, właściwe spojrzenie na śmierć. Dzisiejsza kultura doprowadziła bowiem do banalizacji procesu starzenia się i umierania oraz wykluczenia ich ze społecznego dyskursu (promującego ideał zdrowia i młodości), co potwierdzają m.in. motywy gier komputerowych, reklamy i wszechobecne symbole śmierci na zabawkach dla dzieci, nieumiejętność w towarzyszeniu osobom umierającym, rosnące zapotrzebowanie na hospicja i domy starości, częstsze izolowanie dzieci od doświadczenia śmierci członków rodziny (np. pogrzebu).

\section{Spiralna koncepcja czasu}

Powyższe rozróżnienie pojęć pozwala na uchwycenie istoty tzw. spiralnej koncepcji czasu, stanowiącej specyficzną konstrukcję - połączenie teorii cyklicznej i linearnej. Obie wyżej wymienione koncepcje należą do kategorii tzw. przednaukowych. Zgodnie z wywodzącą się ze starożytności teorią cykliczną, czas można porównać do rzeki - jej źródło i ujście znajdują się w jednym punkcie, a nurt biegnie po okręgu. Czas ma wymiar kosmocentryczny, rytmicznie powtarzalny. Teocentryczna chrześcijańska wizja dokonuje pewnego przełamania kolistego biegu czasu - zaczyna on być postrzegany linearnie, historycznie - pojawił się w momencie stworzenia, a jego wypełnieniem będą czasy ostateczne, koniec świata (Rusiecki 2012, s. 41-42).

Andrzej Fuliński trafnie wskazał pewną prawidłowość w spojrzeniu na czas - dokonał swoistego podziału, rozważając czas w tzw. kontekście natury i w kontekście kultury. W pierwszym aspekcie dzieli się on na czas w ujęciu mechanicznym (który nie rozróżnia przeszłości i przyszłości) i termodynamicznym (posługuje się tzw. strzałką czasu). Analogicznie w kontekście kultury wyróżnia się czas cykliczny (wieczne, niezmienne powracanie wydarzeń) i historyczny - niepowtarzalny, ukierunkowany na cel (Fuliński 2004, 
s. 89-90). To komparatystyczne spojrzenie pozwala dostrzec jeszcze jedną właściwość - podobnie jak w fizyce pojawiły się poglądy, iż „oba te aspekty czasu, mechaniczny i termodynamiczny, trzeba traktować jako komplementarne, w nadziei, że przyszła «ogólna teoria wszystkiego» jakoś je pogodzi” (Fuliński 2004, s. 89-90), tak na gruncie teologicznym dokonuje się zespolenia teorii cyklicznej i liniowej w koncepcję spiralną czasu.

Koncentrując się na istocie koncepcji spiralnej czasu w ujęciu teologicznym i prawnokanonicznym, należy podkreślić, że przedmiotowa teoria ukazuje czas biegnący po spirali, wznoszący się coraz wyżej wokół wektora osi paschalnej - czas jest ukierunkowany na wieczność. Wilfrid Stinissen (1997, s. 13) opisuje tę koncepcję w taki oto sposób:

Spirala jest syntezą tego, co cykliczne i linearne. Wszystko powraca, ale staje się też nowe, ponieważ toczy się na coraz to wyższych poziomach. Klucz do prawdziwego życia znajdziemy właśnie w rozpoczynaniu od nowa, z całą świeżością i otwartością, będąc równocześnie zakorzenionymi we wcześniejszych doświadczeniach i na nich się opierając. Jednostajny rozkład dnia w klasztorach kontemplacyjnych jest typowym przykładem tej „spiralności życia”: nieustannie powtarza się ten sam temat, mimo to jednak wiedzie on ku coraz większej głębi. Człowiek wciąż zaczyna od nowa, a każdy początek może być nowym poziomem, kolejnym stopniem wzwyż.

\section{Czas w prawie}

Zanim zostaną przedstawione szczegółowe rozwiązania dotyczące praktyki duszpasterskiej posługiwania się spiralną koncepcją czasu w prawie kanonicznym, warto przyjrzeć się pokrótce ogólnym zastosowaniom konstrukcji czasu w prawie. Pierwszym jej przejawem jest pojęcie samej normy prawnej: „Każda norma prawna (akt prawny, przepis prawa) obowiązuje w określonym czasie, określone podmioty i na określonym terytorium” (Nowacki i Tobor 1994, s. 141). Odniesienie do czasu dostrzegamy też w określeniu adresata normą generalną, kiedy cechą wyróżniającą jest jego wiek. Podział norm na konkretne i abstrakcyjne jest uzależniony od tego, czy zachowanie wymagane prawem jest zasadniczo powtarzalne czy niepowtarzalne. Okoliczności mogą odnosić się do czasu w sposób bezpośredni, gdy zostaje wyznaczony termin (data) spełnienia czynu, bądź pośredni, gdy termin jest ustalany przez odniesienie do innej czynności czy zdarzenia (Wronkowska 2005, s. 14, 18).

Czas może mieć znaczenie zewnętrzne dla prawa (obowiązywanie i stosowanie norm) bądź wewnętrzne (skutki upływu czasu jako zdarzenia prawnego) (Wasilewski 1966, s. 57-58). Istotne aspekty czasu w porządku prawnym doty- 
czą zarówno obowiązywania normy prawnej, jak i jej wejścia w życie (zaktualizowanie się obowiązku adresata normy co do jej realizacji lub stosowania). Okres pomiędzy wprowadzeniem normy do systemu prawnego a jej wejściem $\mathrm{w}$ życie jest nazywany vacatio legis. Zagadnienie czasu w prawie obejmuje ponadto retroaktywność norm prawnych (zasada lex retro non agit) oraz przepisy intertemporalne, przedawnienie, terminy i ich przywracanie, obliczanie czasu, fikcję prawną przerwy w biegu terminu (Wronkowska 2005, s. 51-60).

Czas odgrywa również istotną rolę $\mathrm{w}$ procesie prawodawczym, $\mathrm{z}$ czym wiążą się zagadnienia trwałości (stabilności) porządku prawnego oraz jego elastyczności (dostosowywanie do zmian zachodzących w rzeczywistości). Jak już zasygnalizowano powyżej, czas określa elementy stosunku prawnego, determinuje powstanie, zmianę i wygaśnięcie stosunku prawnego, decydując zarazem o powstaniu, zmianie i zakończeniu praw czy obowiązków danego podmiotu (Jaskiernia 2004, s. 349-350; Człowiekowska 2011, s. 85-86). Specyficzne jest znaczenie norm moralnych, które mają w pewnym sensie charakter ponadczasowy - ich moc obowiązującą wywodzi się z prawa naturalnego lub $\mathrm{z}$ objawienia, nie będąc $\mathrm{w}$ stanie wyznaczyć początku i końca ich obowiązywania (Jaskiernia 2004, s. 343, 347). Istotną rolę w prawie odgrywają terminy. Termin, wyznaczony jako punkt w czasie lub jako okres (odcinek czasu), oznacza upływ czasu i jest definiowany jako zdarzenie przyszłe i pewne. Terminy pozwalają m.in. na wyznaczanie konkretnego czasu dokonywania czynności prawnych i uporządkowanie ich kolejności, służą zapewnieniu szybkości działania organów państwowych i sądowych czy zagwarantowaniu pewności prawa. Mogą być wyznaczane jako daty dzienne, określane za pomocą liczby lat, miesięcy, dni czy godzin, lub też z wykorzystaniem mniej jednoznacznych zwrotów, jak chociażby: „niezwłocznie”, „ustawicznie”, „tymczasowo”, „w swoim czasie”, ,jak najszybciej”.

\section{Czas w Kościele katolickim i teologii - perspektywa wieczności}

Badając zastosowanie spiralnej koncepcji czasu w prawie kanonicznym, należy uwzględnić specyfikę tegoż systemu prawnego, ponieważ ,cel prawa kanonicznego jest determinowany przez cel Kościoła” (Pawluk 1985, s. 29). Prawo Kościoła katolickiego, duszpasterstwo i ewangelizacja - podobnie jak cała struktura wspólnoty, jej instytucje i wszelkie działania - są podporządkowane nadrzędnej misji: prowadzeniu wiernych do zbawienia. Na kształt norm kanonicznych i przyjętą w nich koncepcję czasu wpływa właśnie owa szczególna perspektywa wieczności, której zasadniczo nie ma w prawie świeckim (poza normami moralnymi, którym w pewnym sensie przypisuje się walor ponadczasowości). 
Jan Paweł II (1994, nr 10) w przełomowym okresie rozpoczynającego się trzeciego tysiąclecia podkreślił, że:

W chrześcijaństwie czas ma podstawowe znaczenie. W czasie zostaje stworzony świat, w czasie dokonuje się historia zbawienia, która osiąg swój szczyt $w$ petni czasu Wcielenia i swój kres w chwalebnym powrocie Syna Bożego na końcu czasów. [...] Z przyjściem Chrystusa rozpoczynają się ostateczne dni (por. Hbr 1,2), ostatnia godzina, zaczyna się czas Kościoła, który trwać będzie do Paruzji. Z tego związku Boga z czasem rodzi się obowiązek uświęcania czasu.

Istotną prawdą chrześcijaństwa jest to, że Bóg objawia siebie w czasie, a przyjście na świat Chrystusa jest punktem zwrotnym historii zbawienia. Jej konsekwencje widoczne są w przejściu od żydowskiej chronologii (liczonej od stworzenia świata i ukierunkowanej na przyszłość) do chrześcijańskiego rachowania czasu (numeracja dwukierunkowa - lata przed i po Chrystusie). Funkcjonowanie Kościoła jako wspólnoty i działanie poszczególnych wiernych wydarza się w czasie, lecz zarazem jest ukierunkowane na wieczność, a każda chwila przybliża albo oddala od upragnionego celu (Bielecki 1999, s. 7-11, 219-236).

Spiralna koncepcja czasu łączy w sobie czas cykliczny i liniowy. Czas kosmocentryczny podlega ciągłej cyrkulacji, co jest widoczne w zmianie pór dnia i nocy czy pór roku, jest poznawalny i zdeterminowany, zamknięty w biegu po okręgu. Biblijny obraz świata ukazuje inny czas - historyczny, liniowy, stworzony ex nihilo i niepoznawalny. Jest on celowy i otwarty. Obie te teorie zostały zintegrowane w teologii: życie człowieka wpisuje się w czas kosmiczny (ruch kolisty) i uwzględnia aspekt chronologiczny (linearny). Wprawdzie czas płynie po kole, ale nie jest to obieg zamknięty - w Słowie natchnionym pojawiają się terminy wyjścia i powrotu: wyjście wyraża stwórczy akt, a nie upadek, zaś powrót oznacza powrót do Boga Ojca, a nie do boskości negującej stworzenie. Oba aspekty czasu w Kościele zostały połączone przez tzw. anamnezę, czyli uobecniające i aktualizujące wspomnienie - przypominające jakieś wydarzenia i powalające je jednocześnie przeżywać w czasie rzeczywistym. Liturgia ma za zadanie jednoczyć przeszłość i przyszłość z teraźniejszością i prowadzić ku wieczności. Powtarzalność i przemijalność kolejnych godzin, dni i lat jest otwarta i uporządkowana, ukierunkowana na nieustanny rozwój i przemianę, odbywa się bowiem wokół wektora, którym jest oś paschalna: misterium męki, śmierci i zmartwychwstania Chrystusa (Stinissen 1997, s. 12-13; Rusiecki 2012, s. 42-49). 


\section{Czas w prawie kanonicznym - inspiracje pastoralne}

Najważniejszym zadaniem Kościoła jest troska o zbawienie wiernych, dlatego są temu podporządkowane: jego organizacja, pochodzące od kompetentnej władzy prawo i podejmowane przezeń działania duszpasterskie. Kanoniczny prawodawca, wykorzystując przedmiotowe koncepcje czasu, konstruuje normy prawne mające na celu pomoc ludziom w osiągnięciu wieczności. W tym dążeniu m.in. ukierunkowuje wiernych na troskę o jakość przeżywanego czasu - przemianę chronos w kairos. Wiąże się z tym cykl roku liturgicznego czy anamneza wydarzeń zbawczych, oparte w swojej konstrukcji na spiralnej teorii czasu.

Spiralna koncepcja czasu znajduje zastosowanie w normach prawa kościelnego o charakterze materialnym, procesowym i ustrojowym. Analiza poszczególnych instytucji prawa kościelnego pozwala w nich dostrzec dominujące elementy bądź to cyklicznej, bądź liniowej koncepcji czasu. Takie rozróżnienie ma jednak charakter teoretycznoprawny, a w praktyce teorie te są zintegrowane w spiralnej koncepcji czasu, na co wskazuje kontekst wykładni funkcjonalnej i systemowej przepisów prawa. Tytułem przykładu wskazać można związek poszczególnych etapów procedury legislacyjnej (uporządkowanych chronologicznie) z określonymi, ważnymi dniami roku liturgicznego (powtarzające się cyklicznie święta, wspomnienia czy oktawy), np. promulgacja pierwszego Kodeksu prawa kanonicznego miała miejsce 27 maja 1917 roku w Zesłanie Ducha Świętego, a termin wejścia w życie tego kodeksu wyznaczono na dzień 19 maja 1918 roku - w tę samą uroczystość; dekret zwołujący archidiecezjalny synod poznański ogłoszono 8 maja 1968 roku - w uroczystość św. Stanisława Biskupa i Męczennika i zarazem z okazji tysiąclecia istnienia biskupstwa poznańskiego. Podobne zasady dotyczą wyznaczania terminów rekolekcji czy zebrań organów władzy kościelnej, jak np. zwołanie szczególnej sesji Kurii Metropolitalnej Archidiecezji Poznańskiej w uroczystość Świętych Apostołów Piotra i Pawła, patronów archidiecezji.

Najbardziej charakterystyczną instytucją prawa kościelnego jest rok liturgiczny i tworzony na jego podstawie kalendarz liturgiczny. Jego istotę w pełni oddają słowa Krzysztofa Koneckiego (2014, s. 5): „Rok liturgiczny to całe życie ziemskie Jezusa od Wcielenia do paruzji, dziś w Kościele aktualizowane i w sposób sakramentalny uobecniane dla naszego uświęcenia i zbawienia”. Kolejne lata można przedstawić w formie spirali, która swoim ruchem wznosi się coraz wyżej w stosunku do punktu wyjścia, zmierzając w kierunku spotkania z Chrystusem. Żaden rok liturgiczny nie jest całkowicie podobny do drugiego. Ponadto jeden rok liturgiczny następujący po drugim zmierzają do Paruzji, w kierunku ostatniego dnia i życia świata, który przyjdzie (Konecki 2014, s. 14). 
Rok liturgiczny odzwierciedla rachubę czasu w Kościele, cykliczne świętowanie wydarzeń $\mathrm{z}$ historii zbawienia i wpisuje się w rytm zmieniających się pór roku. Składa się z naprzemiennych okresów świątecznych i okresu zwykłego, obchodów wspomnień, świąt i uroczystości zgodnie z treścią liturgicznej celebracji skoncentrowanej wokół Misterium Paschalnego. Liturgia łączy w sobie wymiar pamiątki wydarzeń minionych, lecz jednocześnie jest ich uobecnianiem w momencie celebrowania. Z przeżywaniem określonych świąt i kolejnych dni roku liturgicznego łączą się kwestie: codziennej liturgii godzin (tzw. modlitwa brewiarzowa, składająca się m.in. z psalmów, hymnów i czytań odmawianych o określonej porze doby, dobranej stosownie do danego wspomnienia, święta, uroczystości czy dnia okresu zwykłego), cyklu tygodnia rozpoczynanego niedzielą, oktawy - przedłużenia świętowania.

Kościół dla swoich celów nie tylko skonstruował własny, odrębny od świeckiego, sposób liczenia czasu i kalendarz liturgiczny, lecz ponadto kreował swoją terminologię i podziały czasu. Stąd pochodzą m.in. Dni Kwartalne (w środy i w piątki podejmowano post związany z cyklem zmiany pór roku i pracą na roli), sztuka komputu (układania kalendarza liturgicznego zawierającego święta stałe i ruchome), tzw. ogólne normy roku liturgicznego i kalendarza (zawierające np. normy kolizyjne, rozstrzygające, co należy czynić w razie zbieżności świąt, ustalające wigilię - celebrację rozpoczynaną wieczorem dnia poprzedzającego święto), zwyczajowe udzielanie sakramentów i odprawianie nabożeństw w konkretnych dniach i miesiącach roku (np. różaniec w październiku, I Komunia Święta w maju, chrzest w niedzielę, czerwcowe nabożeństwa do Najświętszego Serca Pana Jezusa itd.).

Konstrukcja kalendarza liturgicznego powszechnego i kalendarzy partykularnych (np. dla zgromadzeń zakonnych), cykliczne przeżywanie świąt, celebracja odbywająca się w konkretnych terminach i w ustalonej kolejności, układ świąt stałych i ruchomych, możliwość obchodzenia wspomnień dowolnych, możliwość wypełniania obowiązku uczestnictwa we Mszy Świętej w wigilię uroczystości - wszystkie te instytucje służą zapewnieniu bądź stabilności, bądź elastyczności norm prawnokanonicznych. Warto podkreślić, że tzw. czasy święte (niedziele, święta, posty), dni nakazane, terminy realizacji uprawnień czy obowiązków danego podmiotu są w prawie kanonicznym często określane przez odniesienie do konkretnych świąt czy uroczystości, jak chociażby opisane powyżej wyznaczanie dat ogłoszenia i wejścia w życie kodeksów, odbywania synodów itp.

Większy akcent na cykliczny wymiar czasu kładą koncepcje czasu powracającego wprowadzane w normach prawnych za pomocą zwrotów, takich jak np. „,codziennie”, „każdego roku”, „raz w miesiącu”, ,przynajmniej raz w roku”, „systematycznie”, „regularnie”. Odnoszą się one do obowiązków związanych z sakramentami i przygotowaniem do ich przyjęcia, z uczestnic- 
twem w rekolekcjach czy układaniem planu dnia, ze spotkaniami wspólnot i formacją wiernych, obchodami jubileuszy i rocznic ważnych w sferze duchowej wydarzeń. Powyższą konstrukcję zastosowano np. w treści kan. $514 \S 2$ Kodeksu prawa kanonicznego z 1983 roku - Rada duszpasterska powinna być zwoływana przynajmniej jeden raz w roku - czy kan. $663 \S 3$, wyznaczającego obowiązek dla członków instytutów zakonnych codziennego godnego sprawowania liturgii godzin. Z kolei elementy liniowej teorii czasu uwidaczniają się w większym stopniu w przepisach dotyczących obliczania czasu i obowiązywania prawa oraz normach prawa kanonicznego wskazujących terminy. W szczególności terminy w prawie kanonicznym dotyczą obsady stanowisk, sprawowania aktów kultu i udzielania sakramentów, konkretnych czynności procesowych w sądach biskupich.

Ponadto linearna koncepcja czasu znajduje zastosowanie, jeżeli prawodawca uzależnia wystąpienie danego zdarzenia lub skutku prawnego od urzeczywistnienia w określonym czasie wskazanych wydarzeń, gdy zgodnie z normą prawną pewne konsekwencje mogą wystąpić tylko w danym czasie, kiedy wskazuje na rozróżnienie czasu ciągłego i użytecznego (ten drugi dopuszcza przerwę w biegu terminu, gdy osoba nie wiedziała o przysługującym jej prawie albo wiedziała, lecz nie mogła go realizować), a także jeśli wyznacza pory w liturgii godzin czy wprowadza do porządku prawnego zasadę lex retro non agit. Historyczny upływ czasu zaznacza się w normach regulujących obowiązywanie prawa i reguły jego promulgacji, długości vacatio legis, wejścia aktu normatywnego w życie. W szczególności może się zdarzyć, że obowiązywanie danej normy jest uzależnione od długości istnienia zwyczaju (trzydzieści lat, sto lat lub zwyczaje niepamiętne). Kanoniczny prawodawca wprowadza rozwiązania służące zapewnieniu pewności (stabilności) prawa albo przeciwnie, służące jego większej elastyczności. Wśród nich wyróżnić można instytucje, takie jak przerwa w biegu terminów, czas ciągły i użyteczny, zawieszenie władzy wykonawczej jakiegoś podmiotu, przedłużanie terminów, czasowe i wieczyste śluby zakonne, odraczanie i skracanie terminów w przepisach proceduralnych, stan rzeczy osądzonej, możliwość odstąpienia od reguły podstawowej w uzasadnionych przypadkach (np. „w wypadku konieczności”, „w nagłych przypadkach”, „w sytuacji bliskiej śmierci”, ze względu na ,potrzeby miejsca i czasu").

Wiele norm prawnokanonicznych zawiera w sobie także odniesienie do wieku osoby - adresata danego prawa czy obowiązku - oraz do jego dojrzałości. Zwłaszcza ta ostatnia przesłanka doskonale ilustruje spiralną koncepcję czasu i wyznacza kierunek działań duszpasterskich - wierny, wzrastając w latach, powinien jednocześnie i nieustannie wzrastać w rozwoju psychiczno-duchowym. Przeżywając zatem kolejne lata życia w rytmie roku liturgicznego i uczestnicząc w celebracjach powtarzających się świąt, uroczystości i wspomnień, do- 
świadcza ich corocznie w sposób nowy i celem ewangelizacji powinno być, aby przeżywał je z coraz to głębszym wewnętrznym nastawieniem i perspektywą zbliżającego się przejścia z wymiaru czasu w życie w wieczności.

Normy prawa kanonicznego, w których znajduje zastosowanie spiralna koncepcja czasu, wyznaczają kierunki duszpasterskich działań. Szczególnie istotne jest łączenie ważnych wydarzeń z życia wiernych z cyklem roku liturgicznego poprzez wybór odpowiedniej daty - powiązanie np. przyjęcia sakramentu małżeństwa $\mathrm{z}$ określoną uroczystością bądź wspomnieniem ważnego dla nupturientów patrona oraz jednoczesne nastawienie na cykliczność, tj. obchodzenie rocznic, jubileuszy, będących okazją do głębszej refleksji i wprowadzania pozytywnych zmian. Wyzwaniem dzisiejszych czasów jest pragnienie odnalezienia sensu w znużeniu, pośpiechu i chaosie codziennego życia, odszukanie sfery sacrum poprzez uroczystą celebrację liturgii, pomoc wierzącym w nieustannym dojrzewaniu i pogłębianiu wiary (aby coroczne obchody nie stały się skomercjalizowaną tradycją, lecz były przeżywane na coraz to wyższym duchowym poziomie). Niezbędne do tego jest uruchomienie we współczesnym człowieku procesu samowychowania, również poprzez - niemodną już dzisiaj - ascezę. W doborze środków ewangelizacji należy „,rozeznawać rzeczywistość, w której żyje współczesny słuchacz słowa Bożego” (Dziewiecki 2005, s. 79) oraz „coraz lepiej rozumieć strategie i skutki oddziaływania środków komunikacji używanych w cywilizacji” (Dziewiecki 2005, s. 79), w tym również - wykorzystując możliwości dzisiejszych środków przekazu pomagać w odnalezieniu sensu wydarzeń przeżywanych obecnie w Kościele, w świetle upływającego roku liturgicznego.

Postulatem, na który warto zwrócić uwagę, jest zwiększenie troski o rozwój duszpasterstwa liturgicznego, aby udział w liturgii miał przełożenie na styl życia wiernych, prowadził ich ku realizacji w codzienności postaw prawdziwie chrześcijańskich i owocował nieustannym rozwojem oraz holistycznie pojmowanym wzrostem (Sobeczko 2010, s. 84). Brakuje nam częstokroć świadomości tego, jak wielkie znaczenie może mieć dla człowieka świadome przeżywanie cyklu roku liturgicznego. W tym kontekście biskup Wacław Świerzawski podjął próbę uświadomienia wspólnocie Kościoła, że rolą kalendarza liturgicznego jest nie tylko przypominanie, lecz także uobecnianie misterium zbawienia. Dobre przeżywanie niedzieli jako centrum chrześcijańskiego życia jest życiodajne i owocuje zmianą nastawienia do codziennej pracy, a także świadomym dążeniem do świętości. Biskup wskazał także głębsze znaczenie poszczególnych okresów liturgicznych, np. Boże Narodzenie jako czas wcielania w życie Chrystusowych zasad, okres przejściowy - naśladowanie Jezusa w człowieczeństwie, Wielki Post - wprowadzenie w Misterium Paschalne czy Wielkanoc jako doświadczenie miłości Boga i wtajemniczenie w życie Zmartwychwstałego Pana (Świerzawski 2004). 


\section{Zakończenie}

Przedstawione $\mathrm{w}$ niniejszym artykule rozważania na temat zastosowania spiralnej koncepcji czasu w prawie kanonicznym oraz zaczerpniętych $\mathrm{z}$ niej inspiracji pastoralnych pozwalają w pierwszej kolejności stwierdzić, że $\mathrm{w}$ przedmiotowej teorii kosmocentryczna cykliczność łączy się $\mathrm{w}$ pewien sposób z czasem historycznym, liniowym, ukierunkowując w ten sposób ludzkie dążenia na przejście z czasu ziemskiego w życie wieczne. Ów wymiar nieskończoności stanowi konstytutywną cechę chrześcijańskiej wizji czasu, a kierunek życia wiernych jest wyznaczany przez wektor spirali czasu, jakim jest Misterium Paschalne (wydarzenia męki, śmierci i zmartwychwstania Jezusa Chrystusa).

Taka konstrukcja sprawia, że cykliczne przeżywanie roku liturgicznego, powtarzalność świąt czy przyjmowania sakramentów, wspominanie minionych wydarzeń, pomimo że staje się ponownie czyimś doświadczeniem, odbywa się na coraz to innym poziomie. Celem Kościoła jest formowanie wiernych w taki sposób, aby mijający czas - który jest jednocześnie dany i zadany, otwarty, niepowtarzalny i nieubłaganie przemijający - był wykorzystywany na wzrastanie w dojrzałości i chrześcijańskiej doskonałości. W upływ czasu jest wpisany rytm, pewna regularność. Owa cykliczność została jednak przerwana przez czas linearny i ukierunkowana na wieczność - spirala czasu wznosi się coraz wyżej, ku końcu czasów i w takim kierunku powinien zmierzać całościowy rozwój osoby.

Warto podkreślić, że spiralna koncepcja czasu wykorzystywana w tworzeniu norm prawa kanonicznego i będąca źródłem pastoralnych inspiracji to konsekwencja celów i założeń Kościoła. Jeśli jego misją jest prowadzenie wiernych do zbawienia, konieczna staje się troska o nieustanne nawracanie się, doskonalenie i rozwój - zadaniem duszpasterzy jest troska o to, czym wierni wypełniają swoją codzienność. Ów czas, w liturgii chrześcijańskiej nazywany świętym, rozwija się spiralnie. Nie jest on już zamknięty w biegu po okręgu, w cyklicznej powtarzalności bez celu, bez możliwości przemiany i nawrócenia. Nie jest też możliwe, by płynął liniowo, prosto ku wieczności, ogranicza go bowiem niedoskonała kondycja człowieka, jego życie w przemijającym czasie oraz słabość i grzeszność. Dla chrześcijanina chronos - czas ilościowy - ma sens o tyle, o ile pomaga w przeżywaniu kairos, w zmierzaniu do wieczności i formowaniu się do doskonałej miłości, w dobrym wykorzystaniu danego czasu. Przeżywając każdy kolejny dzień roku liturgicznego i każdy następny rok liturgiczny, uczestniczący w tych samych wspomnieniach, świętach i uroczystościach, znajduje się jednak na innym już stopniu rozwoju. 


\section{STRESZCZENIE}

Autorka w artykule proponuje analizę teoretycznych i praktycznych aspektów spiralnej koncepcji czasu. W pierwszej części wyjaśnia znaczenie pojęć: czas i wieczność, a następnie omawia konstrukcję spiralnej koncepcji czasu. Kolejne części pracy odnoszą się kolejno do aspektów czasowych w prawie, spojrzenia na czas w świetle nauki Kościoła katolickiego i teologii (perspektywa wieczności) oraz do zastosowania spiralnej koncepcji czasu w normach prawa kanonicznego. Przedmiotowa koncepcja stanowi syntezę dwóch innych teorii czasu, tj. cyklicznej i linearnej. Kościelny prawodawca korzysta ze spiralnej koncepcji czasu i konstruuje normy prawne mające na celu pomoc ludziom w odnalezieniu sensu ich życia - wieczności. Istotne jest, aby ukierunkować ich na troskę o jakość przeżywanego czasu - przemianę chronos w kairos. Współcześnie powszechnym doświadczeniem staje się problem nieustannego braku czasu, pośpiechu i lęku przed śmiercią, związany w pewien sposób z utratą perspektywy wieczności. W tym kontekście kairos to czas niosący nadzieję, dający szansę na wyjście z kryzysu i rozpoczynanie od nowa - korzystając z dotychczasowych doświadczeń, powracając do pewnych zdarzeń, lecz przeżywając je niejako w ruchu spiralnym, na nowym, wyższym etapie rozwoju. Autorka zwraca również uwagę, że prawo kanoniczne jest podporządkowane misji Kościoła, która polega na prowadzeniu wiernych do wieczności. Oznacza to konieczność ciągłego rozwoju i dążenia do chrześcijańskiej doskonałości.

Słowa kluczowe: prawo kanoniczne; spiralna koncepcja czasu; czas cykliczny; czas liniowy; rok liturgiczny

\section{A SPIRAL CONCEPTION OF TIME IN THE CANON LAW - PASTORAL INSPIRATIONS}

\section{SUMMARY}

In the article the author proposes the analysis of theoretical and practical aspects of a spiral theory of the time. In the first part she explains the meaning of the terms: time and eternity, afterwards she elaborates the structure of the spiral conception of the time. Consecutive parts of the article refer to temporal aspects in law, the time in the light of the Catholic Church's knowledge and theology (the perspective of eternity) and applications of the spiral conception of time in provisions of the ecclesiastical law. This conception of time connects circular and linear theories of time. The canon law legislator uses the spiral conception of time and lays down legislative acts which should contribute to the regaining the meaning of life - eternity. It is important to help people take good care of how they live and spend their time in order to transform chronos into kairos. The contemporary problem of a continuous lack of time is 
becoming more pressing. Living in a great hurry and fear of death are connected with loss of the perspective of eternity. In view of the above, the author draws the conclusion that kairos is a time that gives hope, a time that gives a chance to overcome crisis and to start over, making use of the previous experiences, getting back on to some occurrences, but experiencing them in a spiral growth, being on a new, superior stage of advancement. The author also pays attention to Catholic mission's domination and canon law's subordination. The pursuit of eternity requires ceaseless progress and growing in Christian perfection.

Keywords: canon law; spiral conception of time; circular time; linear time; liturgical year

\section{BIBLIOGRAFIA}

Augustyn (2013): Wyznania. Tłum. W. Kubiak. Kraków.

Bielecki S. (1999): Chrześcijanin i czas wedlug Listów św. Pawła. Jak rozumieć Pismo Święte? (11). Lublin.

Czas (2006). W: S. Dubisz, L. Drabik, E. Sobol (red.), Uniwersalny słownik języka polskiego PWN t. 1 s. 508-509. Warszawa.

Człowiekowska J. (2011): Czas w materialnym prawie administracyjnym. W: J. Zimmermann (red.), Czas w prawie administracyjnym s. 80-98. I Krakowsko-Wrocławskie Spotkanie Naukowe Administratywistów. Warszawa.

Dziewiecki M. (2005): Komunikacja pastoralna. Kraków.

Fuliński A. (2004): Czas i problemy pokrewne. W: J.A. Janik (red.), Nauka-Religia-Dzieje. XII Seminarium w Castel Gandolfo 5-7 sierpnia 2003. Czas - Wieczność - Nieskończoność s. 89-95. Kraków.

Gadacz T. (2002): Czas. W: D. Kalisiewicz (red.), Wielka encyklopedia PWN t. 6 s. 321. Warszawa.

Jan Paweł II (1994): List apostolski Tertio millennio adveniente. http://nauczaniejp2.pl/dokumenty/ wyswiet1/id/806.

Jaskiernia J. (2004): Kontekst czasu w prawie konstytucyjnym. W: A. Wierciński (red.), The Peculiarity of Man Vol. 9. O naturze czasu s. 341-353. Kielce-Warszawa.

Konecki K (2014): Czas z Chrystusem. Rok liturgiczny. Włocławek.

Nowacki J., Tobor Z. (1994): Wstęp do prawoznawstwa. Warszawa.

Pawluk T. (1985): Prawo kanoniczne wedlug Kodeksu Jana Pawla II. T. 1. Zagadnienia wstępne i normy ogólne. Olsztyn.

Rusiecki J. (2012): Koncepcje czasu a liturgia. W: J. Nowak (red.), Misterium Chrystusa w roku liturgicznym. Ksiega pamiątkowa dedykowana Księdzu Profesorowi Bogusławowi Nadolskiemu TChr z okazji 55-lecia Święceń Kapłańskich i 50-lecia pracy naukowej s. 41-50. Poznań.

Sobeczko H. (2010): Liturgia - liturgika-mistagogia. W: C. Krakowiak, W. Przygoda, A. Kiciński, M. Wyrostkiewicz (red.), Teologia pastoralna nauka w stużbie nowej ewangelizacji s. 63-84. Lublin.

Stinissen W. (1997): Wieczność pośrodku czasu. Poznań.

Świerzawski W.J. (2004): Rok liturgiczny nasza droga z Chrystusem. Duchowość Eucharystyczna. Sandomierz.

Wasilewski A. (1966): Upływ czasu jako zdarzenie prawne w prawie administracyjnym. „Państwo i Prawo" 1:1966 s. 57-66.

Wronkowska S. (2005): Podstawowe pojęcia prawa i prawoznawstwa. Poznań. 
Jolanta Kostecka, mgr, doktorantka w Katedrze Prawa Rzymskiego i Historii Prawa Sądowego Wydziału Prawa i Administracji Uniwersytetu im. Adama Mickiewiczaw Poznaniu; e-mail: jolanta.gajewska@amu.edu.pl. 